\title{
Ife Oracle in Itsekiri Social System of Nigeria
}

\author{
Jackson Omasanjuwa Ireyefoju $\mathrm{u}^{1, *}$, Florence Ejuogharanmakelesan Ireyefoju ${ }^{2, * *}$ \\ ${ }^{1}$ Department of Social Studies Education, College of Education, Warri, Delta State, Nigeria \\ Phone No. 08038748571 \\ ${ }^{2}$ Department of Languages, College of Education, Warri, Delta State, Nigeria \\ Phone No. 07069518461 \\ ${ }^{*, * \star E-m a i l ~ a d d r e s s: ~ b e s e j u d i t h @ g m a i l . c o m ~, ~ a m e g o l d b l i s s @ y a h o o . c o m ~}$
}

\begin{abstract}
Itsekiri people came from Egypt after the battle of Actium in 31 B.C. They arrived and settled in the present Warn Kingdom in about 28 B.C in Gborodo, Ureju and Ode Itsekiri. The leaders of the teams were Iset, Iweret and Ipi. The word Oritse which means God in Itsekiri appears to be closer to Osiris, god of the Nile than those of their neighbours - Urhobo, Ijaw and Ilaje. Ra, the god of the sun in Egypt that helps the crops to mature is the wife of Umalokun in Itsekiri, the provider of sea foods. Ife oracle with its 256 literary corpus is a compendium of the cultural practices of the people. It includes the metaphysical and psychic studies of the people, a source of ethics and discipline of the people. It must be sustained to raise the spiritual level of the people. The phenomenological approach was employed by the authors to examine the historical configuration of the Itsekiri social system and the place of Ife oracle. It was concluded that Ife oracle, as compendium of knowledge and reality, is the access point to understanding our human inheritance and realizing our core values. Upon this, it was recommended that Ife oracle is not fetish. Rather it is a valid and reliable source of knowledge.
\end{abstract}

Keywords: Ife Oracle; Itsekiri Social System; African Cosmology; Oral Literature; Integrated Curriculum

\section{INTRODUCTION}

Ife oracle, a compendium of knowledge, is an aspect of Itsekiri social system. History, philosophy, religion and language can be integrated because of their relationship in the humanities. English and Itsekiri languages shall be used. Much more attention shall be given to ltsekiri language and its role among the people.

The history of Itsekiri has many versions which are almost being hinged on Ilaje and Bini. Today Itsekiri language is said to be Yoruboid, but Agharowu and Olomu (2008) made it clear that Olugbo was around before the advent of Oduduwa to Ile-Ife. Olugbo moved down South West to settle at the present site of Ugbo. Ilaje is a dialect of Yoruba now but Itsekiri, according to Yoruboid classification, is very distinct from Ilaje and popular Oyo.

Recent findings about the aborigines of Itsekiri hinge on Iset, Iweret and Ipi all from Egypt to present Warri kingdom in about 28B.C. The people left Egypt during the battle of Actium between Augustus Octavian Caesar versus Mark Anthony and Cleopatra of Egypt. 
They found places like Gborodo. Iset and Ipi lived there and Iweret occupied Odeitsekiri with Seikiri. Gborodo is very far from Ode-Itsekiri but they speak the same language without dialectal differences. The people of Gborodo have no quarter in Ode-Itsekiri like other ltsekiri settlements of the era of Olu Atogbuwa, Erejuwa I and Akengbuwu I. The people of Inorin, Omadino and Ureju are pre-Ginuwa, the first Olu in 1480 but the Olu and his people were quickly absorbed into Itsekiri language like the Romans who conquered the Greeks but were civilized by the Greeks.

The people, Iset, Ipi Seikiri and Iweret came with some religions. Most of the gods were of the water. For example, the Itsekiri national anthem confirms this position:

\author{
Ara oloriri afomasin \\ Oluromi owami Ogie \\ Ira wo gba gba mije \\ Mon gbe ji were \\ Ira we gba gbamije mon \\ Guara guoro \\ Ara olorire afomasin \\ Oluromi owami Ogie.
}

$R a$ was a sun god in Egypt that ripened the crops for the people to eat. Osiris was the god of the Nile which washed the desert banks with silt for luxuriant growth of the crops. The Edo called God Osalobua, Ilaje called him Olorun and Itsekiri say Orise which is closer to Osiris in Egypt than any of the first two. They were appeasing the god of the Nile twice every year.

In the book of Exodus 13:1-16 animal sacrifices were done, when a donkey gave birth to a male donkey for the first time. Abraham was to offer Isaac to God as a sacrifice but replaced him with a ram and the sun god no longer received human blood. To do that becomes a sin. Some eminent personalities in Nigeria lost either a wife or a child at certain age. Such people do not die earlier than 80 and above.

The statistics are everywhere among some cults in Nigeria. Jephter offered his only daughter as sacrifice to God when he came from war successfully. He must have given the child as an atonement for the sins he committed in the war. This is exemplified in Hebrews $8: 21 \& 22$.

ltsekiri was using Albino (Afen) to appease the god of the sea. Later they changed it to white he-goat. Most of the effective war shrines were appeased every year with blood. Some of such shrines include Benikurodo and Afinayan of Usele, Osunya of Daleoketa, Opuegba of Ebrhimi and Koko, Osankporo of Deghele, Osonikia of Jakpa and Oro of Ureju. In Okere it is Ogungbaja Okere di Ola and Ugbokua of Gbolokposu.

They were all like cults and people were initiated into them. Their principles of operation were never trivialized. And they were sacred and sancrosant. Anybody that contravened the laws was surely going to suffer for them. They were revealed by lfe Oracle. It should be noted that there is difference between Religion and Morality. A person could have sound moral without being religious. 


\section{LANGUAGE, HISTORY AND RELIGION}

How language was discovered by men is still part of natural miseries. Engel (1948) said when articulate languages were discovered people began to reduce wandering and itinerant life. Nomadism reduced considerably except a few who did not want to abstain from Aryan life of movement. Aryans were cattle rearers who came to Egypt, Greece and other parts of Middle East to establish intellectual breed that brought about men of ancient wisdom, based on psychic and metaphysical studies. They gradually gave birth to science. These were based on monocemic approaches embodied in nature, discovered by intuition and developed by logical reasoning.

Itsekiri, Ijaw and Urhobo of the Niger Delta in South South Nigeria are neighbours but do not share similar culture. They share service and obedience to different deities assumed to be responsible for their protection and predicaments. Evil, the measure of goodness is always unacceptable by the deities except a few that need blood before being potent enough to protect the people.

Itsekiri as a people communicate with the spirit world through Ife oracle. The 256 literary corpus of Ife oracle in Itsekiri have distinct esen, names with their oracular languages - Ogbe. They are logical coupled with oratory and poetic expressions. They may sound open ended to the ignorant who does not understand the metaphysical concepts of the Ife oracular languages. Ramakacharaka (1978) said words are images and symbols that constitute evil and good which the spirit of truth discerns to apportion blame on the people according to their contributions.

Ife oracle with its arranged literary corpus is anti-evil among the Itsekiri. This is basically found among these Ogbe: Obara - blood, Igite obara - evil deed

\section{Oghorilogbin ti oda \\ Oghori mi no Ukuti ofe \\ Kpa imino ka wi Ugogoro}

This implied that the evil that men do lives after them.

They are arranged in cosmic language, and the ability to use the pass words to open the seal is learned. Words like Owun (incantation), Ogbe (Ife language), "Odu" (pass words) must also be studied. These are part of levitation and psychic study. These words raise the Ife oraclist level of clairvoyance to discuss the past deeds and make futuristic conclusions during divination.

Plato divided knowledge into three - mathematics, logic and oratory. He concluded by saying that they were products of intuition and part of the latent, natural aspect of man. English Education System that regimented Africans reduced their thought system and probably left them with material acquisition, a process described by Egharegbemi (1968) as treating the less privilege as human beast. There is need to go back to the indigenous culture to use Ife oracle in all its ramifications because Rosicrucian, Grail Message, White Eagle, Ancient and Free Masonry and Yogi practices are in African cultural practices, which could be explored to prove the validity of our practices.

History of the people must have suffered a lot of distortions. Initially, the Arabs that entered Nigeria from the Northern part of the country had their own version. Igala that assumed to have been around before the Yoruba accepted Itsekiri as their brothers and sisters that came almost the same time from the East (Abdullahi, 2006). There are many related words in Igala and Itsekiri. Olukumi and Ebu share a lot of expressions with Itsekiri, not 
much from their aquatic neighbours of the Niger-Delta. Some of the people from Ebu are part of the seven groups that constitute Gborodo. They all worship Iset, the leader of the group that was deified.

Itsekiri system of governance is gerontocracy, but priests are highly reverend at every occasion. For instance, Gborodo, Ureju and Okere leadership is paternal, not necessarily by age. They are allowed to preside over every meeting that involves discussion of the deities because their existence is claimed to be controlled by ancestors and spiritual forces, particularly those from the seas.

Against this African cosmology, religious practices among the people were regarded by the Europeans as paganism because they wanted rationalized moral system to cushion the effects of slavery and slave trade that lasted for over 300 years. The first slave consignment from Warri, Gborodo and Tebu, was in 1479 before Warri kingdom was found in 1480 (Lloyd, 1956).

The concept of indoctrination and mental regimentation overtime had caused a lot of unreasonable emotional reactions in our religious practices. For example, Rev. Fr. Avery (in Nduka, 1965:42) said:
Surely the time is over due when Christians in Sierra Leone should not be forced into the schizophrenic (hallucination, emotional instability) type of religious life. If the churches want to make more vital and wider spread impact, they will have to try more sincerely these African sacrifices and appreciate the fact the sentiments which engendered them are genuinely religious and by no means entirely pagan and unchristianly. An appropriate base on which to proceed might be the sacrificial nature of Eucharist or the Lord's Supper.

The Holy Eucharist or the Lord's Supper is a modified continuation of what came out of the Feast of Passover in about 1446 B.C when Moses led the Jews out of Egypt into the Holy Land. There were series of levitation activities (spiritual practices) that sustained the Jewish belief system thus the Jews were able to follow Joshua to the Holy Land.

The Ife oracle, like events in space with its monocemic storage of concepts into different compartments, helps the consulting priests of high level of clairvoyance to tap much information beyond the world of sensibility. Ife oracle priests, like inspired prophets, do not flicker when revealing divine messages to a people.

Europeans missionaries discouraged metaphysical practices by establishing schools that encouraged rote learning and record keeping. Astral travelling was not taught. Nigerians were not allowed to put on traditional parchments for protection. Some spiritual incantations were not allowed but Joshua called the hornets to drive the Amonites out of the Jews' way. Some such recitation of serious outcome may be cited.

Ubokan owun Oligun oko kani gba Iu ewere. Obon eka wo di amama Oyibo. Ganaga owum ra ka ri okoyibo. Usi obon owun ra ka gbo gba na obon.

It may be literarily translated as, for mere understanding without being able to apply it,

Pofada (snake) does not go about in search of prey. Its prey comes to where it lives. An illuminated environment shows different colours. No matter the 

population of Nigerians in a market square, Europeans are conspicuous. A
well organized market attracts customers.

There are much to this metaphysically than the mere recitation of it. It is enshrined in Ife oracle as Idinose. It is used as a spell or to mesmerize a person.

A study of Ife oracle among the Itsekiri is much more than 256 literary corpus that constitute the conceptual compartments and the interpretations. Ife oracle is a compendium of knowledge in Itsekiri, Yoruba and Igala metaphysical studies.

\section{ITSEKIRI SOCIAL SYSTEM}

The word Itsekiri is very foreign to Nigeria. Most of them coined the following from it at its original version: (a.) Isekiri ene - people protected by blessing; (b.) Isekiri aghan people set aside with special prayers and so on.

When Prince Ginuwa came to found the Iwere kingdom in 1480, people were around. The IJaw of Isiloko that paddled the canoe which brought the Prince and his entourage from Bini speak the Edo language. Hence they were able to assist them (the Prince and his subjects) with their canoes down to establish the kingdom. Itsekiri language was already predominant before they came, thus they were not able to dominate the Itsekiri linguistically.

Talbot (1926) and Hussey (1933) describe the Ijaw as people with shady history. They did not fail to accept them as being one of the earliest people in the Niger-Delta. Williams (in Benike, 2002) said the Ijaw had been around for some six thousand years ago. It means the Ijaw were in the region before the Exodus of the Jews in 1446 B.C. The Ijaw are the closest neighbours of the Itsekiri in the Niger-Delta region.

Itsekiri has the following class: (1) Otonolu (Royals), (2) Omajaja (king-makers), (3) Ibiedo (domestic workers), (4) Egungun (people with shady historical origin), and (5) Ejoji (Strangers). It should be noted that royals are never made priests at any public shrine or masquerades. They are the overlord at every point. A disregard of a royal can result into something that the ancestors do not cherish. It could be mentioned by Ife oracle when the ancestors or shrines are being appeased. An Itsekiri proverb succinctly put it this way:

\section{Eru eka kpa Oton olowa. Or Osan ekaja gba kpa irumu ti owi edon ro.}

Translation: A slave does not kill his master's child. Or a shrine does not kill the grass around it.

This is because everybody is at the mercy of the Olu and the royals. It is only Ife oracle that proves them wrong for anything contrary to the ancestors and shrines, not the masquerades. The only masquerade the royals reverend is Birikimo at Orugbo. It is the Olu that authorizes its celebration. The Olu is above all the shrines and the masquerades in Itsekiri, not the royals in all cases because indiscipline is not a virtue in Itsekiri. Nobody in the Niger-Delta glorifies acts of indiscipline.

\section{CONCLUSION}

The Ife oracle was the only element in the Itsekiri social system Western culture was unable to influence. Therefore the starting point for rebuilding and understanding human inheritance, and realizing core values in Itsekiri social system is through the Ife oracle, a compendium of knowledge and reality. 


\section{Recommendations}

The richness of Ife oracle in terms of language, knowledge and values reveals that it is a repository of the language and it should be studied. It may not necessarily be for divination, but the oratory and poetic aspects enshrined in it are of great value to knowledge, linguistic and social development.

This is because its inspirational, motivational and emotional languages could be used in analyzing certain issues and situations in our lived experiences. Although, the inspirational aspect of Ife oracle is for divination, it can also be used as source of disciple. For it explores and expresses the lived experiences of the people thereby creating anxiety and hope in the people. Ife oracle has a spiritual premise that covers the practices of Itsekiri thus its significance at every point are immeasurable. Ife oracle is not fetish, primitive, rather it is a valid and reliable source of knowing in traditional African experience. Going on astral journey takes different dimensions.

Hence there is no peculiar way of doing it. Therefore there is need to delve into what it is in our own culture to dig out the process and significance of spiritual development. Subjects in the humanities will go a long way to assisting learners in realizing the spiritual aspect of life. Monocemic projection as aspect of human consciousness does not only lead to critical outlook, it equips learners with skills and social abilities to live the happy life.

\section{References}

[1] Abdullahi J. (2006). The First Nigerian People. Abuja: NNPD Publishers.

[2] Agharowu E. E., Olomu A. O. O. (2008). History of Warri (C3400-1480AD). Warri: Victous Global Enterprises.

[3] Benike J. (2002). How the Federal Government and the Multinationals Underdevelop the Niger Delta. Warri: Cogito Creative Publishers.

[4] Egharegbemi T. A. (1968). Human Understanding. Warri: Daifopil Publishers.

[5] Engel F. (1948). The Origin of the Family Private Property and the State, Moscow: Progress Publishers.

[6] Hussey E. R. J. (1933). The Teaching of Geography and History, Lagos: Oxford University Press.

[7] Lloyd P. C. (1956). Tribalism in Warri: Proceedings of the Conference of the West African Institute.

[8] Nduka O. (1965). Western Education and Nigerian Cultural Background. London: Oxford University Press.

[9] Ramacharaka Y. (1978). Yogi Philosophy and Oriental Occultism. USA: Chadwell L. N. Fowler \& Co. Ltd.

[10] Talbort T. A. (1926). People of Southern Nigeria. London: Macmillan.

[11] Odo John Ogar, International Letters of Social and Humanistic Sciences 8(1) (2014) 28-33. 
[12] Elizabeth Morenikeji Titilayo Adediran, Albert Oluyomi Kehinde, International Letters of Social and Humanistic Sciences 8(1) (2014) 66-75.

[13] Sanusi L. Sa'adatu, International Letters of Social and Humanistic Sciences 8(2) (2014) 140-147.

[14] Rowland U. Aleshi, Clementina N. Iloh, International Letters of Social and Humanistic Sciences 8(3) (2014) 208-216.

[15] Fowoyo Joseph Taiwo, International Letters of Social and Humanistic Sciences 8(3) (2014) 244-251. 